\title{
Technological capacity of manufacturing enterprises in the North Central Vietnam: Current Status, Issues and Policy Implication
}

\author{
Nguyen Thi Minh Tu \\ Nghe An Social Sciences and Humanities Center \\ 126 Ly Tu Trong, Vinh City, Nghe an Province \\ minhtu311@gmail.com
}

\author{
Tran Van Hoang \\ Vietnam Institute of Economics, VASS \\ 1B Lieu Giai, Ba Dinh Dist., Hanoi \\ tranvanhoang11@gmail.com
}

\begin{abstract}
Applying Barney's theory of resource-based development and evaluation criteria, and Lall's technological capability classification framework, this article analyzes the operational efficiency and the technological and innovation capabilities of manufacturing enterprises in the North Central region of Vietnam, using firm survey data conducted by the General Statistics Offices (GSO) in period 2011-2019. Comparing with other regions, firms in the North Central region are overwhelmingly of micro and small scales with relatively poor operational efficiency and low level of technological and innovation capacities.
\end{abstract}

Index Terms - North Central region; Manufacturing; Enterprise; Technology capacity, $R \& D$, innovation.

\section{INTRODUCTION}

$\mathrm{T}$ HE $13^{\text {th }}$ National Party Congress of Vietnam set a target that by 2030 , Vietnam would become an industrialized and upper-middle income country. In order to achieve this target, the country needs to quickly improve labor productivity, especially in the industrial sector, which has remained quite low. In such a long time, Vietnam followed a model of large-scale industrial development, which focused on attracting a high volume of foreign direct investment (FDI) while not considering as much about the quality of FDI. The comparative advantage of Vietnam still bases on natural resources and low labor cost. Up until now, the majority of FDI and private enterprises in Vietnam operates in low-tech and low-value-added industries.

While sharing several common characteristics, there are heterogeneity across regions, with regards to the structure, performance and technological development of firms. This paper sheds light on the manufacturing sector of the North Central region of Vietnam, in comparison with other regions and the country as a whole. Though being rich in natural resources, for decades, this region lagged behind some other regions (i.e the Red river delta, the Mekong river delta or the South East region) due to its under-developed infrastructure. In recent years, the National Government has allocated more resource to advance the region's infrastructure, resulting in better market access and connectivity with major economic centers of the country. As a consequence, the North Central region is becoming more attractive to foreign and private investors. Several big investment projects have been established in the region (such as Formosa Factory in Ha Tinh province; Dung Quat Oil Refinery project in Nghi Son economic zone in Thanh Hoa province, the agricultural project of TH True milk in Nghe An province). This improves that the region still has a lot of potentials to further attract investment to improve its economic development level. In addi- tion, enhancing the growth of firms and their performance in this region will contribute greatly to the overall realization of the development target of Vietnam.

This paper focus on analyzing the performance and the current state of technology and innovation capacity of manufacturing enterprises in the North Central region of Vietnam. This topic has not been studied much in literature. In addition, the paper also aims at pointing out some policy implications for the local governments to further develop the manufacturing sectors in this region.

\section{Analytical Framework}

\section{A. Methodology}

To assess firms' technological capacity, this paper focuses on two criteria: the technological level of the main manufacturing industry and the level of the main technology used in production.

Firstly, following the classification proposed by Lall (2000), high-tech industries include the following sub-sectors: chemicals and chemical products manufacturing; drugs manufacturing, pharmaceutical chemicals, and herbal ingredients manufacturing; electronic manufacturing, computer and optical products manufacturing; electrical equipment manufacturing; unclassified machinery and equipment manufacturing; manufacture of motor vehicles and trailers; other means of transport manufacturing and medical, dental, orthopedic and rehabilitation equipment and instruments manufacturing. Middle-tech industries include: Producing products from rubber and plastic; other non-metallic mineral products manufacturing; metal production; shipbuilding; other unclassified manufacturing industries; and repair, maintain and install machinery and equipment. Low- tech industries include: food production and processing; beverage production; tobacco production; weaving; costumes production; leather and related products production; wood processing; paper and paper products production; print, copy records of all kinds; production of coke, refined petroleum products; manufacture of products from prefabricated metal (except for machinery and equipment); and beds, figures, and chairs production.

Secondly, the technological level of the main production machinery used in enterprises is classified as followed: (i) low-tech (main machines used are hand tools); (ii) middletech (main machines used are semi-automatic machines); and (iii) high-tech (main machines used are fully automatic machines). 
In addition, the study compares technological levels of firms across regions and types ownership.

\section{B. Data}

The study uses survey data on the technological capabilities of manufacturing and processing enterprises conducted by the GSO in the period 2011-2019. The survey is conducted annually to access the performance of firms in Vietnam. In the period 2011-2014, the annual sample size was from 7,000 - 8,000 enterprises, but in the later year, the sample size decreased to only 4,000 - 5,000 enterprises. However, the sample structure is still representative at a regional level. The share of the number of enterprises in the North Central region in the sample remains quite stable during the period of study (i.e. $5.25 \%$ in $2011-2014$, and $4.82 \%$ in 2015-2019, respectively).

\section{Result And Discussion}

\section{A. General characteristics of manufacturing enterprises in the North Central region}

Regarding firm's size based on the number of employees, the region hosts mainly micro and small manufacturing firms. In the period 2011-2014, they accounted for $67.4 \%$ of all manufacturing firms in the region, compared to an average of $46.2 \%$ of the whole country. In the period $2015-2019$, the proportion decreased to $50.7 \%$, but still higher than the national average of $29.8 \%$. The share of large-scale enterprises in the region is also considerably lower than the national average (15\% versus $36 \%$, respectively) (See Figure 1).

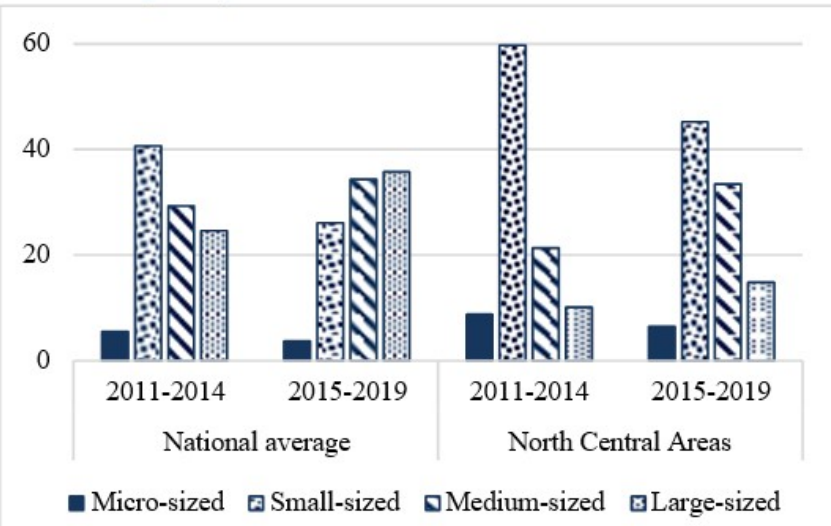

Figure 1. Composition of manufacturing enterprises in the North Central region by size

Source: authors' calculation

The high share of micro and small firms in the region shows some signs of limited capital capacity - which is crucial for firms to invest in improving technology and to invest in innovation.

This is true when we look at the size of firms' capital. In the period 2011-2014, a typical manufacturing enterprise in the North Central region had the capital of nearly VND 34 billion with a scale of 79 employees, much smaller than that of the South East region (the region with the largest scale of enterprises in Vietnam) with corresponding figures of VND 142.5 billion and 260 employees. In the period 2015-2019, the scale of manufacturing enterprises in the North Central region has changed in a positive direction, with an average capital of VND 68.1 billion and 99 employees. However, it is still inferior to the average enterprises in other regions.

Table 1 provides information on firm size, either by capital or employee size, of enterprises in seven economic regions of Vietnam. It can be seen that the North Central region is among the lowest ranking regions.

TABLE 1. CAPITAL AND LABOR SOURCES OF MANUfACtURING ENTERPRises STRUCTURE BY ECONOMIC REGION

\begin{tabular}{|l|c|c|c|c|}
\hline \multirow{2}{*}{ Region } & \multicolumn{2}{|c|}{$2011-2014$} & \multicolumn{2}{c|}{$2015-2019$} \\
\cline { 2 - 5 } & $\begin{array}{c}\text { Capital } \\
\text { (bil. VND) }\end{array}$ & $\begin{array}{c}\text { Labour } \\
\text { (person) }\end{array}$ & $\begin{array}{c}\text { Capital } \\
\text { (bil. VND) }\end{array}$ & $\begin{array}{c}\text { Labour } \\
\text { (person) }\end{array}$ \\
\hline Red River Delta & 94.8 & 193 & 198.4 & 309 \\
\hline \begin{tabular}{l|c|c|c|c|} 
Northern Midlands \\
and Mountains Areas
\end{tabular} & 57.1 & 167 & 109.0 & 249 \\
\hline North Central Areas & 33.8 & 79 & 68.1 & 99 \\
\hline Central Coast & 68.6 & 186 & 171.6 & 285 \\
\hline Central Highlands & 50.1 & 87 & 60.0 & 84 \\
\hline South East & 142.5 & 260 & 271.1 & 386 \\
\hline South West & 96.0 & 216 & 225.0 & 392 \\
\hline
\end{tabular}

Source: authors' own calculation

Regarding types of ownership, in the period 2015-2019, most of the manufacturing enterprises in the North Central region are in the domestic private sector. The share of firms belong to private, FDI and state sectors are $92 \%, 7 \%$ and $1 \%$, respectively. The share of FDI firms in this region is significantly lower than the national average of $32.6 \%$ (See Figure 2 for more details).

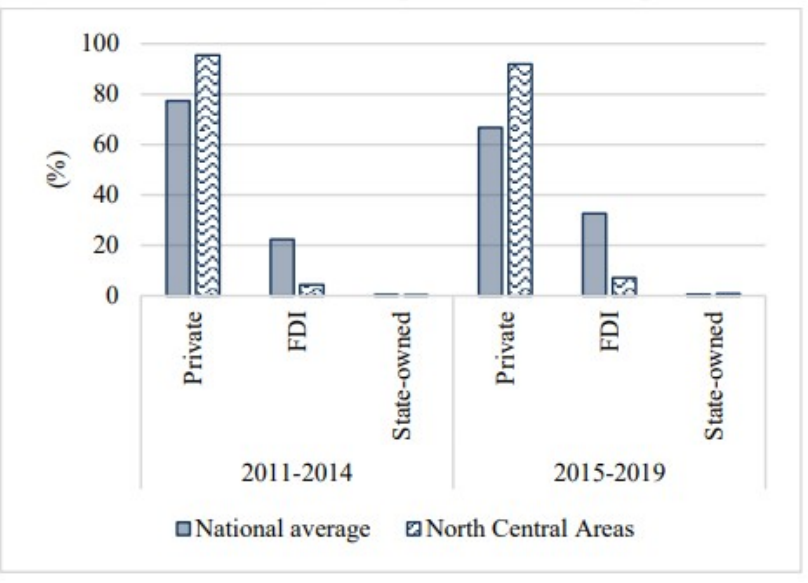

Figure 2. Composition of firm by ownership Source: authors' calculation.

\section{B. Operational efficiency of manufacturing enterprises in} the North Central region

\section{1) Operational efficiency by capital}

The study examines 3 criteria to evaluate the efficiency of capital use of manufacturing enterprises, including: net revenue per capital, pretax profit per capital, and export value per capital. Our results show that, the ratio of net revenue/ capital of the Northern Central region is among the three lowest regions in the country, but the ratio of pre-tax profit/ capital source of the North Central region manufacturing enterprises is relatively good. However, firms in this region mainly focus on local labor market, and the ratio of export revenue over total capital is quite low (Table 2). 
Table 2: Capital Use Efficiency of Manufacturing Enterprises By Regions, 2011-2019.

\begin{tabular}{|l|r|r|r|r|r|r|}
\hline \multirow{2}{*}{\multicolumn{1}{|c|}{ Region }} & \multicolumn{2}{|c|}{$\begin{array}{c}\text { Net } \\
\text { revenue/capital }\end{array}$} & \multicolumn{2}{c|}{$\begin{array}{c}\text { Pre-taxes } \\
\text { Profit/capital }\end{array}$} & \multicolumn{2}{c|}{ Export/capital } \\
\cline { 2 - 8 } & $\begin{array}{l}2011- \\
2014\end{array}$ & $\begin{array}{l}2015- \\
2019\end{array}$ & $\begin{array}{l}2011- \\
2014\end{array}$ & $\begin{array}{l}2015- \\
2019\end{array}$ & $\begin{array}{l}2011- \\
2014\end{array}$ & $\begin{array}{l}2015- \\
2019\end{array}$ \\
\hline $\begin{array}{l}\text { Red River } \\
\text { Delta }\end{array}$ & 1.33 & 1.32 & 0.92 & 1.96 & 0.12 & 0.07 \\
\hline $\begin{array}{l}\text { Northern } \\
\text { Midlands and } \\
\text { Mountains }\end{array}$ & 1.22 & 1.34 & 1.01 & 1.02 & 0.44 & 0.14 \\
\hline North Central & 1.28 & 1.24 & 2.33 & 1.50 & 0.10 & 0.15 \\
\hline Central Coast & 1.53 & 1.50 & 2.01 & 2.20 & 0.05 & 0.03 \\
\hline $\begin{array}{l}\text { Central } \\
\text { Highlands }\end{array}$ & 1 & 0.84 & 0.88 & -2.86 & 0.03 & 0.12 \\
\hline South East & 1.96 & 1.51 & 2 & 3.07 & 0.15 & 0.18 \\
\hline South West & 3.35 & 3.73 & 3.33 & 3.25 & 0.95 & 0.24 \\
\hline
\end{tabular}

Source: authors' calculation.

\section{2) Operational efficiency by labor (Labor use efficiency)}

We examine labor use efficiency by looking at average revenue and profit per employee. The results are presented in Table 3. In the period 2011-2014, an average labor in the region generated about VND 418 million in gross revenue per year, which is the lowest in the country. Although in the period 2015-2019, this number increased significantly to nearly VND $763.6 \mathrm{mil} /$ worker/year, it was still the second lowest region in the country, only higher than the Central Highlands and far behind the South West region (the region with the best labor productivity in the country) - VND 1.96 billion/labor/year.

However, in terms of profit, the North Central region has quite good labor efficiency. In the period 2011-2014, an employee of a typical manufacturing enterprise in the North Central region earned VND 12 million per year in profit for the firm, this is the 3rd best rate among second economic regions. In the period 2015-2019, the ability to generate profit increased significantly to VND 17.8 million, but was still significantly lower than other regions.

Disaggregating by firm types, FDI manufacturing enterprises are most efficient in using labor by gross revenue, followed by state-owned enterprises and private sector enterprises. Table 3 shows that in the period 2015-2019, a typical employee in an FDI manufacturing enterprise generated more than VND 2 billion in net revenue/year, 2.4 times higher than state-owned enterprises and nearly 3 times higher than private sector enterprises (Table 4).

Table 3. Labor Use Efficiency of Manufacturing Firms By Region, 2011-2019 Unit: MIL. VND/LABOUR

\begin{tabular}{|l|c|c|r|r|}
\hline \multicolumn{1}{|c|}{ Region } & \multicolumn{2}{c|}{ Net revenue/labor } & \multicolumn{2}{c|}{ Profit before tax/labor } \\
\hline \hline & $\begin{array}{c}2011- \\
2014\end{array}$ & $\begin{array}{c}2015- \\
2019\end{array}$ & $2011-2014$ & $\begin{array}{c}2015- \\
2019\end{array}$ \\
\hline Red River Delta & 677.8 & $1,126.5$ & 3.0 & 20.3 \\
\hline $\begin{array}{l}\text { Northern Midlands and } \\
\text { Mountains Areas }\end{array}$ & 460.7 & 762.7 & -1.6 & 0.2 \\
\hline North Central Areas & 418.2 & 763.6 & 12 & 17.8 \\
\hline Central Coast & 529.1 & 927.6 & 6 & 14.2 \\
\hline Centrals Highlands & 459.2 & 606.4 & 4.5 & -16.5 \\
\hline South East & 862.0 & $1,237.5$ & 17.9 & 49.9 \\
\hline South West & $1,459.7$ & $1,958.7$ & 14.6 & 20.1 \\
\hline
\end{tabular}

Source: authors' calculation.
Table 4. Labor Use Efficiency of Manufacturing Firms BY OWNERSHIP, 2011-2019 UNIT: MIL. VND/LABOUR

\begin{tabular}{|l|r|r|r|r|}
\hline & \multicolumn{2}{|c|}{ Net revenue/labor } & \multicolumn{2}{c|}{ Profit before tax/labor } \\
\cline { 2 - 5 } & $2011-2014$ & $2015-2019$ & $2011-2014$ & $2015-2019$ \\
\hline State enterprises & 392.4 & 749.2 & -24.2 & 7.3 \\
\hline Private Company & 366.2 & 655.3 & 5.5 & 7 \\
\hline FDI enterprises & $1,572.9$ & $2,169.1$ & 159.1 & 158 \\
\hline
\end{tabular}

Source: authors' calculation.

\section{Technological capacity of manufacturing enterprises in the North Central region}

1) Technology level by business line

The North Central region has the manufacturing enterprises structure by the technology level of the "relatively modern" industry. On a national scale, the majority of manufacturing enterprises operate in industries with low technology levels, accounting for $62.7 \%$ in the period $2011-2014$ and $57.4 \%$ in the period $2015-2019$, while this rate of the North Central region was $50.1 \%$ and $43.9 \%$, respectively. The percentage of manufacturing enterprises operating in the middle technology industries of the North Central region is also significantly higher than that of the national average, nearly 2 times (Figure 3 ). In the period 2011-2014, the average rate of manufacturing enterprises operating in the technology industry in the region accounted for $41.7 \%$, then increased slightly to

$43.8 \%$ in the period $2015-2019$. While the national average rate is $23.7 \%$ and $24.4 \%$, respectively.

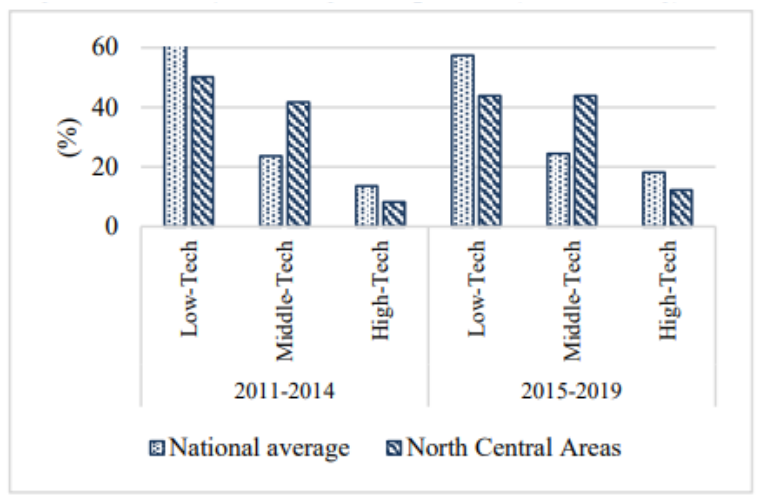

Figure 3. Manufacturing enterprises by technology levels Source: authors' calculation.

However, the proportion of manufacturing enterprises operating in high-tech industries in the North Central region is relatively lower than the national average, which is a limitation (Figure 3). But the positive point is that the proportion of manufacturing enterprises operating in the region's hightech industry has improved significantly over time. Indeed, in the period of 2011-2014, only $8.3 \%$ of enterprises in the North Central region operated in the high-tech industry. This rate increased to $12.3 \%$ in the period 2015-2019.

\section{2) Production technology capacity of manufacturing}

enterprises in the North Central region

Most of the manufacturing enterprises in the North Central region use middle-level technology (semi-automatic machines). The average number of enterprises using semi-automatic machines accounted for nearly $86 \%$ in the period 
2011-2014 and this figure increased to more than $90 \%$ in the period 2015-2019. However, the share of firms using hightech machinery has remained quite stable in the past 10 years. (Figure 4).

While the level of technology does not change much, firms in the North Central region have been quite actively in innovating their production technology. Figure 5 shows the sensitivity of production technology of manufacturing enterprises, that is, the correlation between the time when production machines are created and the time when enterprises use those machines in production.

The results reveal that the high concentration on line 45 degree shows that enterprises in the North Central region use relatively new and updated machines "regularly".

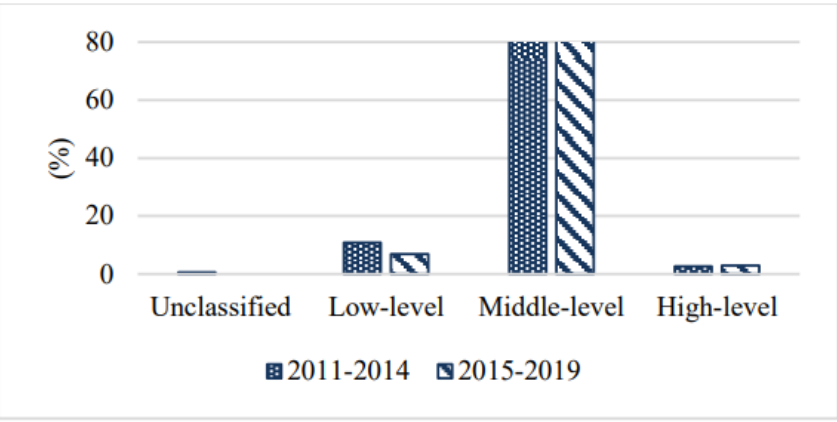

Figure 4. The technological level of the main production machinery in the enterprise. Source: authors' calculation.

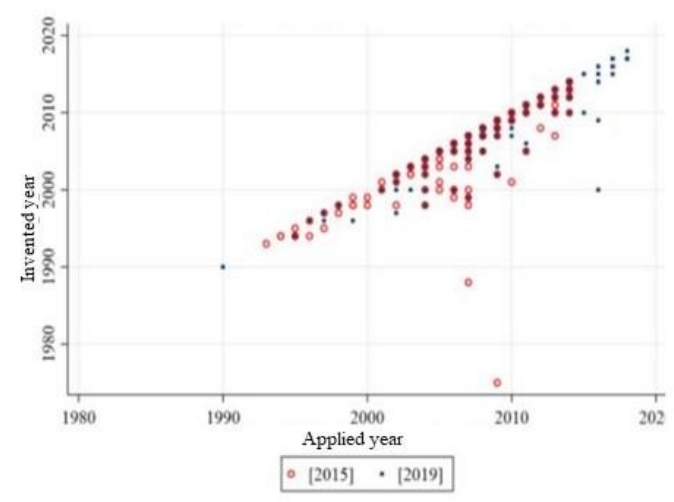

Figure 5. Sensitivity of production technology of NC region manufacturing enterprises. Source: authors' calculation.

In terms of the technology origin - the place where machinery and equipment are manufactured3, most North Central enterprises use machinery and equipment manufactured domestically or imported from China. In the period 20112019 , the proportion of enterprises using domestically manufactured machinery decreased, but the number of enterprises using machinery imported from China tended to increase. The rate of using machinery imported from developed countries with advanced technology is quite limited.

With close economic relations along with the popularity of Japanese FDI enterprises in Vietnam, manufacturing enterprises in the North Central region import many machinery and equipment from Japan Meanwhile, the proportion of imported machinery from other high-tech countries such as the US, Western Europe, and newly industrialized countries (Korea, Taiwan, Hong Kong, Singapore - NICs) remains quite limited - less than 10\% (Figure 6).

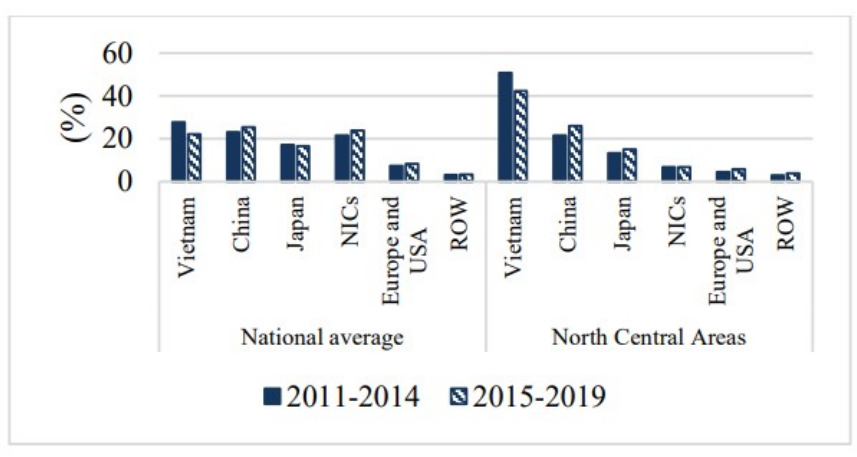

Figure 6. Main countries supplying manufacturing production machinery. Source: authors' calculation.

\section{3) The innovation capacity of manufacturing} enterprises

Innovation capacity is assessed through the proportion of enterprises with R\&D activities. Survey data show that, in the period 2015-2019, the rate of enterprises with R\&D activities in the North Central region was $5.3 \%$, that is, out of 100 enterprises of public policy in the region, only less than 6 enterprises have developed R\&D activities. This rate is lower than that of the national average of $6.9 \%$. This shows the limitation of the innovation capacity of enterprises in the region (Figure 7).

In terms of how R\&D activities are carried out, local manufacturing enterprises mainly self-deploy $52.3 \%$ or combine between self-implementation and outsourcing, which accounts for $43.5 \%$, hiring other organizations to carry out R\&D activities under the enterprise's order take place at a very limited rate - less than 10\% (Figure 8).

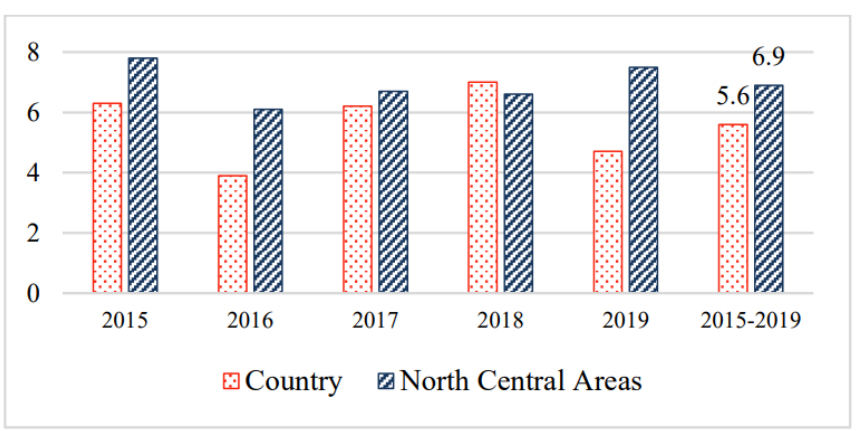

Figure 7. Percentage of firms carrying out R\&D in the North Central region, 2015-2019. Source: authors' calculation.

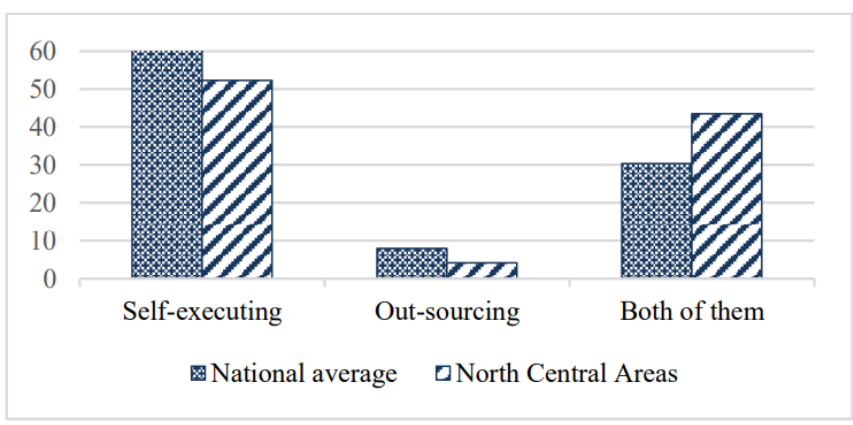

Figure 8. R\&D practices of manufacturing firms in North Central region, 2015-2019. Source: authors' calculation.

Most manufacturing enterprises carry out R\&D activities for the purpose of improving the quality of existing products and advancing production processes thereby enhance opera- 
tional efficiency. Expansion goals such as diversifying products, expanding into new fields, and changing to new business activities are less concerned (Figure 9).

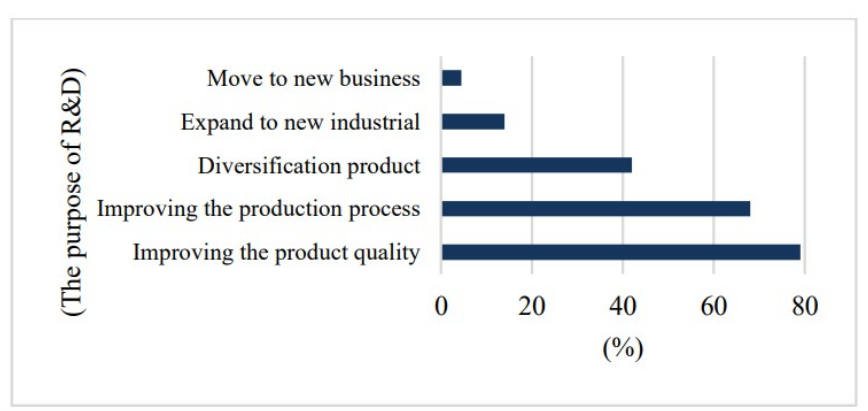

Figure 9. Main objectives of R\&D activity, North Central region, 2015-2019. Source: authors' calculation.

Regarding the budget for R\&D, the survey results show that most of the enterprises in the North Central region use their own capital or loans. Meanwhile, on a national scale, businesses can mobilize capital from other sources such as support from the national/regional budget, joint ventures with other organizations, and a number of other sources.

\section{Some issues in improving technological capacity and innovation of public service enterprises in the North Central region}

Technological innovation and innovation capacity of manufacturing enterprises in the North Central region are still limited, lagging much behind other regions: manufacturing enterprises are mainly SMEs with limited resources and limited access to capital to conduct technological innovation. Technological innovation in enterprises is still modest, does not have a long-term vision of technological innovation and improvement for sustainable development.

Research and development (R\&D) is still only an additional activity in enterprises and only implements some asynchronous stages. There are very few enterprises that carry out $R \& D$, even lacking $R \& D$ capacity.

The human resources of the current manufacturing enterprises are still weak, unable to meet the requirements of receiving new and modern technologies.

State policies have not encouraged enterprises to invest in technology. Lack of a legal framework to encourage innovation in enterprises. There is no mechanism to encourage the use of the institute's workforce to participate in innovation, improvement and technological development at enterprises.

The link between manufacturing enterprises and research institutes - universities and state management agencies in innovation, technology transfer and development remain weak.

\section{Conclusion}

With the above situation and problems, in order to improve the technological capacity and innovation of the enterprises in the North Central region, attention should be paid to:

(1) Attracting more large-scale investment projects in the region. Currently, the majority of firms in the North Central region are of micro and small scale, hence lack of resources to update technology or to conduct R\&D. In general, larger firms will have more resources and more incentives to invest in technology and innovation. In order to attract large investors, the region should continue to invest more on infrastructure, improving business environment, and more importantly to design a clear and specific strategy to attract investment.

(2) As most enterprises in the region use their own capital or credit loans to update technologies or to innovate, it is necessary to made available more sources of capital support for firms. The national and local government should spend a larger amount of public budget to support firms to innovate, and more importantly, to make the budget more accessible to firms.

(3) Other sources of funding for R\&D should also be given priority: venture capital for innovative start-up, public-private partnership, and university-enterprise collaboration.

\section{REFERENCES}

[1] Ahmad, N., Othman, S. N., \& Mad Lazim, H. (2014), 'A review of technological capability and performance relationship in manufacturing companies. ISTMET 2014 - 1st International Symposium on Technology Management and Emerging Technologies, Proceedings, (May 2015), 193-198

[2] Avlonitis, A. J., Kouremenos, A., \&Tzokas. N. (1994), 'Assessing the Innovativeness of Organizations and its Antecedents: Project Innovstrat'. European Journal of Marketing, 28(11), 5-28

[3] Barney, J. (1991), 'Firm resources and sustained competitive advantage', Journal of management, 17(1), 99-120

[4] Barney, J. B., Mackey, A., Mackey, T. B., (2007), 'Corporate social responsibility and firm performance: Investor preferences and corporate strategies', Academy of management review, 32(3), 817-835.

[5] Barney, J. B., Ketchen Jr, D. J., \& Wright, M. (2011), 'The future of resource-based theory: revitalization or decline?', Journal of management, 37(5), 1299-1315.

[6] Bell, M. \& Pavitt, K., 1993, 'Technology accumulation and industrial growth: contrasts between developed and developing countries. Industrial and corporate change. Vol 2. No.2.

[7] Chen, C.J. (2009), 'Technology commercialization, incubator and venture capital, and new venture performance'. Journal of Business Research, 62(1), 93-103;

[8] Chuang, L.M., Liu, C.C., Tsai, W.C. and Huang, C.M. (2010), 'Towards an analytical framework of organizational innovation in the service industry'. African Journal of Business Management, 4(5), 790799

[9] Chantanaphant, J., Nabi, M. N. U., \& Dornberger, U. (2013), 'The Effect of Technological Capability on the Performance of SMEs in Thailand'. The Macrotheme Review, 2(4), 16-26

[10] Lall, S. Technological capabilities and industrialisation. World Development, 20 (2), 1992, 165-186.

[11] Lall, S. (2000). The technological structure and performance of developing country manufactured exports, 1985-98. Oxford Development Studies, 28(3), 337-369. https://doi.org/10.1080/713688318

[12] Pavitt, K. (1993). Technological Accumulation and Between Developed and Developing.

[13] OECD (2021), Báo cáo chính sách DNNVV và khởi nghiệp tại Việt Nam.

[14] World Bank (2020), Báo cáo khoa học, công nghệ và đổi mới sáng tạo Việt Nam.

[15] Duy, N.Q. (2015), 'Đổi mới sáng tạo và các nhân tố tác động - Tổng kết cơ sở lý thuyết', Tạp chí Kinh tế và Phát triển, 221(2), 37-46.

[16] Trần Ngọc Ca, Tăng Thu Thảo, Đặng Thanh Tùng (2018), 'Học hỏi và xây dựng năng lực công nghệ doanh nghiệp thông qua kết nối với đối tác nước ngoài: một số kinh nghiệm quốc tế và thực tiễn Việt Nam', Tạp chí chính sách và quản lý KH\&CN, Tập 7, số 3 (2018), 24-39

[17] Hoàng Văn Cương, Đinh Hải Hà, Nguyễn Xuân Toàn (2021), 'Hoàn thiện thể chế cho hoạt động đổi mới sáng tạo của doanh nghiệp', Tạp chi KH\&CN Việt Nam, số 6/2021, 14-15.

[18] Nguyễn Hoàng Hải (2017), 'Một số gợi ý về thúc đẩy phát triển năng lực công nghệ ở Việt Nam', Tạp chi Khoa học ĐHQGHN: Nghiên cúu chính sách và quản lý, số 1(2017). 